\title{
Effect of Home-Processing on The Antioxidant Properties of Apricot Products
}

\author{
Asteer V. Abd- Elnoor ${ }^{1}$
}

\begin{abstract}
This paper seeks to examine the effects of processing apricots at home in different ways on the antioxidant activity. Raw, boiled, puree, juice and apricot jam that were processed at home were examined for their total carotenoids, total flavonoids (TF), total phenolics (TP) and total antioxidant activities. The results showed that apricots are rich in fiber and mineral, the most important of which are potassium and phosphorus. Puree and jam had the highest total phenolics and total flavonoids content compared to raw apricot, boiled and juice. In addition, puree, and jam had the highest total antioxidant activities compared to other products. There were no significant differences in the carotenoids content among raw, boiled, puree, jam and Juice of apricot. This research provides detailed analysis to examine the effects of different methods of apricots' home processing on the antioxidant potential of different apricot products.
\end{abstract}

Keywords: Apricot; Total phenolic; Total flavonoids; Carotenoids; Total antioxidant activities; Homeprocessing.

\section{INTRODUCTION}

Apricot is the commonly used name of Prunus armeniacaL. (Rosaceae), which is a fruit known for its sweet taste. It is also known as Armeniaca vulgaris L. in Latin It is a fruit that is cultivated in a well differentiated seasonal environment. Apricot grows in a relatively cold weather and quite high temperatures in spring and early summer (Ahmadi et al., 2008). The plant is between 2 to $10 \mathrm{~m}$ tall and its fruits kernel are generally hard not soft. Apricots ripen toward the end of July and the beginning of August. Yet, the harvest varies depending on the climate in these months. The flavor of the apricots is distinctly sweet with a delicious smell, and taste. Its color varies between yellow, orange, with an exterior reddish cover, which is connected with apricot quality parameters (ErdoganOrhan \& Kartal, 2011).

Customers across the globe like this delicious fruit and it has its own great economic value for many years. People like to eat fresh, frozen and dried apricots or they may make it juice, jam, nectars, pulp, orange and apricot jam, jellies, and other edible products (Chauhan et al., 2001). Moreover, according to Yildiz et al. (1994), oil for cooking, cosmetic products, benzaldehydes and active carbon are extracted from the kernels of the apricot.

Apricots have mutli-nutritional and medicinal values; Iordanescu and Micu (2012) argued that apricots are recommended for vitamin A deficiency, anemia, mental and physical fatigue, stress, and depression. Apricots are useful for the nervous system and they strengthen immunity of the body and natural response, since apricots result in an alkaline action, as they maintain the balance of the acid in the body tissues and blood. Apricots can reduce the acidity arising from eating meals that contain too much meat and flour ingredients. Apricot is rich with the main minerals such as $\mathrm{Mg}, \mathrm{Ca}$, and K (Drogoudi et al., 2008). Also, Apricot is rich with the lycopene substance that protects from cancer, heart disease, and reduces cholesterol in the body. Samples of apricots have been examined to find out their antioxidant impact, their effect on improving human health has been shown (Leccese et al., 2010). It has been found out that apricots are very rich with compounds that have an antioxidant effect such as vitamin $\mathrm{C}$, carotenoids, and polyphenols (Fratianni et al., 2018).

The fresh apricot contains rich volatile compounds, vitamins $\mathrm{K}$ and $\mathrm{C}$, carotene, thiamine, and niacin. Terpenoids, phenols, carbohydrates, esters, and organic acids have also been isolated (Sefer et al., 2006). Apricot kernels contain a huge quantity of dietary protein, along with important quantities of oil and fiber (Hacıseferogulları et al., 2007). Apricot is a seasoned fruit that does not last long due to the increasing rate of breath and short period of ripening (Egea et al., 2007).

Apricot is anexpensive fruit that is not accessible as a raw fruit in many nations. As a result, there is acapability for the manufacture of apricot to make products from raw apricots in order to satisfy market demands and for economic gain. Products from apricot are extremely demanded by customers due to their unique aroma, taste, and nutritional benefit.

Various techniques of conservation, including canning, packaging, drying, freezing in controlled air environments (Jimenez et al., 2008) and processing into different products, have been created to extend the shelf life of apricot. Nevertheless, we cannot 
ignore the fact that processing may affect the ratio of the nutrient components. The loss of nutrients in fruit and vegetables depends on the kind of food, processing temperature, processing time and how the food is stored (Murcia et al., 2001). Some methods of preservation may also cause the depletion of the antioxidants that occur naturally in foods, and consequently reduce their health protection effect (Kalt, 2005).

The present work was conducted to assess the impact of home-processing on the antioxidant capacity apricot pulp and compared it with non-processed apricot.

\section{MATERIALS AND METHODS}

\section{Materials}

About $5 \mathrm{~kg}$ of fresh apricot which were brought from a small market of vegetables and fruits in Alexandria Governorate, Egypt.

Solvents and chemical substances used in this study were obtained from El-Gomhorya Company and faculty of Agriculture Alexandria, Egypt.

\section{Methods}

\section{Preparation of apricot products}

The apricot fruits were variously processed at home resulting in different types of apricot products including puree, boiled, juice, and jam as shown in Figure 1.

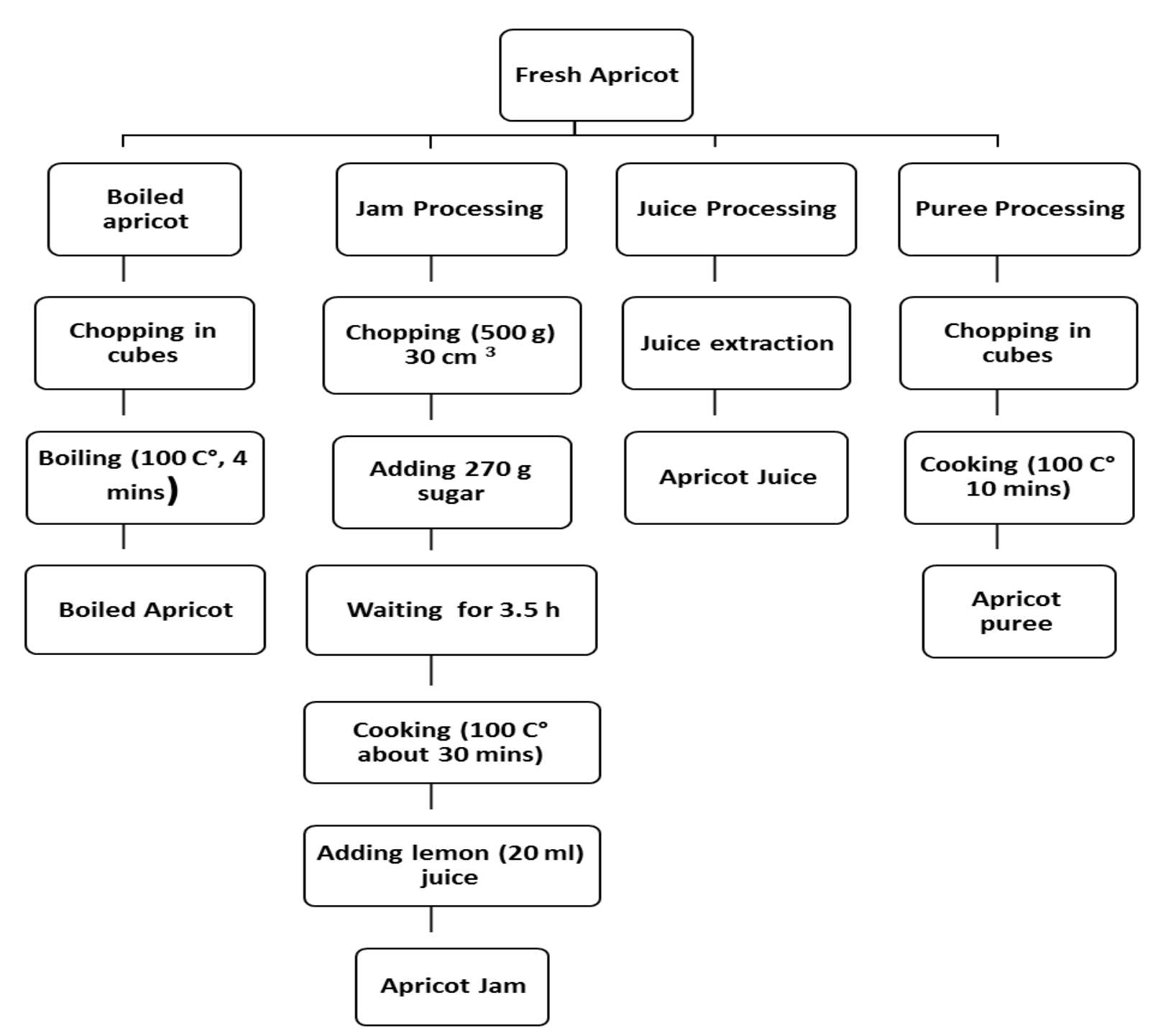

Fig. 1. Home processing methods of boiled, jam, juice and pureed apricot products 


\section{Determination of proximate composition}

Moisture, ash, protein and fat content were determined according to AOAC (2007). The total carbohydrates content was calculated by subtracting $100 \%$ of the total protein, fat, moisture and ash content.

\section{Mineral analysis}

The AOAC (1990) method was used in the determination of mineral contents of apricots.0.8-1 $\mathrm{g}$ of apricot samples were heated at a temperature of $550 \pm$ $10^{\circ} \mathrm{C}$ for 6 hours in a muffle furnace and the remaining ash was left in a water bath with 5-ml $6 \mathrm{M} \mathrm{HCl}$. 7-ml 0.1 $\mathrm{M} \mathrm{HNO}_{3}$ was added then the contents were diluted to $100 \mathrm{ml}$ with double-deionized water as outlined by Nielsen, (1994). Manganese (Mn), iron (Fe), copper $(\mathrm{Cu})$, calcium $(\mathrm{Ca})$, selenium $(\mathrm{Si})$, magnesium $(\mathrm{Mg})$, and zinc ( $\mathrm{Zn}$ ), were determined by (ECIL Atomic Absorption Spectrophotometer -4141). potassium (K) and sodium $(\mathrm{Na})$ were determined by flame photometer (Systronics-130) and phosphorus (P) using a spectrophotometer (SystronicsIndia UV-vis 108).

\section{Extract Preparation}

Three separate quantities from each sample were conducted using acidified ( 0.1 per cent formic acid) aqueous-methanol (75 per cent) as outlined by Capanoglu et al. (2008). Five grams of each sample were extracted with $5 \mathrm{~mL}$ of extraction solvent and were put in an ultrasonic bath (Azakli, Istanbul, Turkey) for fifteen min, then the samples were centrifuged by Hettich Zentrifugen Universal 32R, Hettich Zentrifugen, Tuttlingen, Germany for $10 \mathrm{~min}$ at $4000 \mathrm{rpm}$ at $5{ }^{\circ} \mathrm{C}$ and the supernatant has been gathered. A further $5 \mathrm{~mL}$ of extracting solvent was added to the pellet and the extraction operation was repeated. Two supernatants were combined and stored at $-20{ }^{\circ} \mathrm{C}$ until assessment was done.

\section{Determination of total phenolics content}

To determine the total phenolics content (TP), the reagent Folin-Ciocalteau was used, based on a technique modified by Singh et al. (2002). An extract of $200 \mu \mathrm{L}$ of the sample was added to $1 \mathrm{~mL}$ of newly prepared Folin-Ciocalteau reagent (the proportions were $1: 10$, v/v with $\mathrm{MQ}$ water). Subsequently, $0.8 \mathrm{~mL} 7.5 \%$ sodium carbonate solution was added. The extraction was left for thirty minutes at room temperature and the absorbance was recorded using a UV-Vis spectrophotometer at $765 \mathrm{~nm}$, (Shimadzu UV-1700; Shimadzu Corporation, Kyoto, Japan). Results were presented as $\mathrm{mg}$ gallic acid equivalents (GAE) per $100 \mathrm{~g}$ of wet weight of the fresh sample.

\section{Determination of the total flavonoids content}

The total content of the flavonoids (TF) was identified using the technique of Čanadanovic'-Brunet $e t$ al. (2011). one $\mathrm{mL}$ of sample extract was added to $4 \mathrm{~mL}$ of distilled water and $300 \mu \mathrm{L} \mathrm{5 \%} \mathrm{NaNO2}$ solution. The mixture was left for five minutes and then $300 \mu \mathrm{L}$ of $10 \% \mathrm{AlCl}_{3}$ and $2 \mathrm{~mL}$ of $1 \mathrm{M} \mathrm{NaOH}$ were added to the mixture after an additional $6 \mathrm{~min}$ of incubation. The final volume was reached up to $10 \mathrm{~mL}$ with MQ water. The TF content of extracts was determined as rutin equivalents (RE) and absorption was evaluated at 510 $\mathrm{nm}$ per $100 \mathrm{~g}$ of wet weight of fresh apricot.

\section{Determination of the total antioxidant capacity}

The total antioxidant capacity (TAC) of the extracted samples was assessed through the use of DPPH $(1,1-$ diphenyl-2-picrylhydrazyl) test. The DPPH assay was conducted as outlined by Ravichandran et al. (2012). Six $\mathrm{mL}$ of the stock solution of DPPH $\left(1^{\mathrm{x}} 10-3 \mathrm{M}\right)$ were diluted in $100 \mathrm{~mL}$ of $75 \%$ methanol to get the reaction of DPPH solution. After that, $100 \mu \mathrm{L}$ of each sample extract was blended with $3.9 \mathrm{~mL}$ of DPPH reaction solution. After 30 minutes of dilution the absorbance of the blend was measured at $515 \mathrm{~nm}$.

The $\mathrm{IC}_{50}$ is described as the concentration of antioxidant required to reduce the initial DPPH concentration at least to $50 \%$. The $\mathrm{IC}_{50}$ of the samples was obtained from the percentage scavenging activity vs. concentration plot and it is expressed as $\mathrm{mg} / \mathrm{ml}$.

\section{Determination of the total carotenoids content}

The carotenoid content was measured according to Choi et al. (2002). One gram of the sample was added to $10 \mathrm{ml}$ of extracting solution (hexane: ethanol: acetone, $50: 25: 25, \mathrm{v} / \mathrm{v} / \mathrm{v})$. The top layer of hexane containing carotenoids was restored after the expulsion for $10 \mathrm{~min}$ at $5000 \mathrm{rpm}$, next the absorbance was estimated at 430 $\mathrm{nm}$. To measure the carotenoid content reference a calibration curve was employed by using $\beta$-carotene.

\section{Statistical analysis}

By using IBM SPSS program (version 20.0), the data were analyzed (Armonk, NY: IBM Corporation). Also, using mean and standard deviation of quantitative data were explained. The obtained results are considered significant when measured at the 5\% level (Kotz et al., 2006). To compare between two groups under study, the normally distributed quantitative variables were used $(\mathrm{t}-$ test). 


\section{RERSULTS AND DISCUSSION}

\section{The proximate chemical composition of apricot fruit}

The proximate chemical composition of raw apricot is shown in Table (1).The values of moisture, protein, lipids, ash, carbohydrate and calories were found to be $84.00 \pm 0.15,0.80 \pm 0.35,0.55 \pm 0.13,5.16 \pm 0.51,9.49$ $\pm 0.50(\mathrm{~g} / 100 \mathrm{~g} \mathrm{WW})$ and $46.11 \pm 0.48(\mathrm{~K} \mathrm{cal} / 100 \mathrm{~g})$, respectively.

An overview of the chemical composition of apricot fruit in previous researches shows that the chemical composition of apricot fruit varies according to its varieties ( Iordanescu et al., 2012), agricultural practices (Leccese et al. 2010), ripening (Ayour et al., 2017), geographical region (Campbell et al., 2011), and processing or conservation technology (Hussain et al. 2013).

Hacıseferoğulları et al. (2007) noted that the concentration of carbohydrate in fresh apricots ranges from 11 to 13 percent and provides $50 \mathrm{kcal}$ of energy per $100 \mathrm{~g}$ on wet weight basis. Fats and proteins are exist in small quantities in the apricot fruit; but, the kernel of the apricot has significant quantities that vary from 20 30 percent to 40-52 percent (Alpaslan and Hayta, 2006). The percentage of protein and fat in apricot fruit ranged between $1.4-2.0 \%$ and $0.4-0.6 \%$, respectively. Also, Ali et al. (2015) found that on dry weight basis, it has an elevated dietary content of sugars (over 60\%), total minerals $(4 \%)$, proteins $(8 \%)$,crude fat $(2 \%)$, crude fiber $(11.50 \%)$, vitamins(extremely rich in vitamins $\mathrm{B}$, $\mathrm{C}$, and $\mathrm{K}$ complex) and sensible amounts of organic acids (malic acid and citric acid).

\section{The mineral content of apricot fruit}

The elements contents in fresh apricot are shown in Table 2. Potassium was the most abundant mineral in apricot. The range of potassium content was $292.0 \pm 0.69$, further, it is followed by phosphorus, calcium and magnesium $(17.0 \pm 0.14,13.0 \pm 0.84$ and 8.0 \pm 0.05 , respectively). The contents of $\mathrm{Fe}$ and $\mathrm{Si}$ were $0.51 \pm 0.03$ and $0.39 \pm 0.25 \mathrm{mg} / 100 \mathrm{~g} \mathrm{WW}$, respectively. Fresh apricot contained a low amount of sodium and manganese $(1.0 \pm 0.04$ and $0.05 \pm 0.04 \mathrm{mg} / 100 \mathrm{~g} \mathrm{WW}$, respectively).

These results are consistent with the findings found by Ali et al., (2011) that apricots contain different quantities of essential minerals. The main components are magnesium, phosphorus, selenium, potassium, iron and calcium), while copper, manganese, sodium and zinc are also present in small quantities (USDA, 2005).

Wani et al. (2015) found a major variation $(P \leq$ $0.05)$ in the mineral quantities in the examined apricot flesh (Chinese, Tilton, Rival, Cuminis Haley, Margulam, Harcot, Narmu, Halman, Khante, Cuba and BadamChuli). In the apricot species, $\mathrm{Ca}, \mathrm{Zn}, \mathrm{Fe}, \mathrm{Cu}, \mathrm{Na}$, $\mathrm{Mg}, \mathrm{K}, \mathrm{P}$ and $\mathrm{Mn}$ were found in the range of 15.62 $372.66, \quad 0.5-6.74,0.9-12.62,0-0.82, \quad 14.85-28.06$, 23.35-64.29, 2,150-5,416.66, 9-696, and 0-0.98 ppm, respectively. $\mathrm{Zn}, \mathrm{Cu}$, and $\mathrm{Mn}$ minerals were found in the samples but in very small amounts while $\mathrm{Fe}, \mathrm{K}, \mathrm{P}, \mathrm{Ca}$, and $\mathrm{Mg}$ levels were found in macro amounts in the species studied. Potassium, $\mathrm{Mg}$, and $\mathrm{Ca}$ are considered as the major apricot fruit minerals (Drogoudi et al., 2008). It is known that magnesium is vital to the metabolism of chlorophyll and to the proteins synthesis, lipids, and carbohydrates. The deficiency of this element results in a reduced concentration of carotenoid (Negrea et al., 2012). Hussain et al. (2010) revealed that the amount of $\mathrm{Fe}$ in apricots ranges from 1.4 to $2.4 \mathrm{mg} 100$ $\mathrm{g}-1$, based on the apricot types. Minerals level in the varieties of the studied apricot may be genetically changed and affected by environmental situations. It is known that minerals in crops differs according to the composition of the soil in which the plant is implanted (Soetan et al., 2010).

Table 1. Proximate composition of fresh apricot (WW \%)

\begin{tabular}{lcccccc}
\hline & \multicolumn{6}{c}{ Chemical composition (WW \%) } \\
\cline { 2 - 7 } $\begin{array}{l}\text { Fresh } \\
\text { apricot }\end{array}$ & $\begin{array}{c}\text { Moisture } \\
(\boldsymbol{\%})\end{array}$ & $\begin{array}{c}\text { Proteins } \\
(\boldsymbol{\%})\end{array}$ & $\begin{array}{c}\text { Lipids } \\
\mathbf{\%})\end{array}$ & $\begin{array}{c}\text { Ash } \\
(\boldsymbol{\%})\end{array}$ & $\begin{array}{c}\text { Total } \\
\text { carbohydrates } \\
(\boldsymbol{\%})\end{array}$ & $\begin{array}{c}\text { Calories } \\
(\mathbf{K a l} / \mathbf{1 0 0 g})\end{array}$ \\
\hline & $84.00 \pm 0.15$ & $0.80 \pm 0.35$ & $0.55 \pm 0.13$ & $5.16 \pm 0.51$ & $9.49 \pm 0.50$ & $46.11 \pm 0.48$ \\
\hline
\end{tabular}

Values represent means \pm standard deviation of triplicates. $* * *$ Total carbohydrates calculated by difference.

Table 2. Mineral analysis (ppm WW) of fresh apricot

\begin{tabular}{ccccccccccc}
\hline & \multicolumn{10}{c}{ Minerals Concentration $(\mathbf{m g} / \mathbf{1 0 0 g W W})$} \\
\cline { 2 - 11 } parameters & $\begin{array}{c}\text { Calcium } \\
(\mathbf{C a})\end{array}$ & $\begin{array}{c}\text { Phosphorus Magnesium } \\
(\mathbf{P})\end{array}$ & $\begin{array}{c}\text { Iron } \\
(\mathbf{M g})\end{array}$ & $\begin{array}{c}\text { Potassium } \\
(\mathbf{F e})\end{array}$ & $\begin{array}{c}\text { Selenium } \\
(\mathbf{K})\end{array}$ & $\begin{array}{c}\text { Manganese } \\
(\mathbf{S i})\end{array}$ & $\begin{array}{c}\text { Sodium } \\
(\mathbf{M n})\end{array}$ & $\begin{array}{c}\text { Copper } \\
(\mathbf{N a})\end{array}$ & $\mathbf{( \mathbf { C u } )}$ \\
\hline Apricot & $13.0 \pm 0.84$ & $17.0 \pm 0.14$ & $8.0 \pm 0.05$ & $0.51 \pm 0.03$ & $292.0 \pm 0.69$ & $0.39 \pm 0.25$ & $0.05 \pm 0.04$ & $1.0 \pm 0.04$ & $0.06 \pm 0.03$ \\
\hline
\end{tabular}

Values represent means \pm standard deviation, $\mathrm{WW}=$ Data presented on wet weight basis 


\section{PHYTOCHEMICALS IN APRICOT}

Apricot contains different concentrations of phytochemicals like polyphenols (phenolic acids and flavonoids) and carotenoids which are responsible for their color, taste and nutrient benefits (Dragovic-Uzelac et al.,2007).

\section{Total Phenolic Content}

The findings obtained for the total phenolic contents of fresh and other apricot products showed that the puree sample contains $94.55 \pm 0.42 \mathrm{mg}$ gallic acid equivalent (GAE)/100 g (Figure 2) compared to fresh sample. In addition, the total phenolic values were higher in jam $(75.37 \pm 0.87)$ than in the fresh sample (55.21 $\pm 0.62 \mathrm{mg}$ GAE/100 g sample). This can be explained by the finding of $\mathrm{Xu}$ et al. (2007) that the free fraction of phenolic acids increased after heat treatment. Cooking has been shown to increase the vegetable phenolic content due to food dehydration and the increase of phenolic extraction in products (Schweiggert et al., 2006).

Figure 2 shows that the steps of processing apricot (especially boiling) did not have considerable effect on the total phenolics value in comparison with fresh apricot $(P \leq 0.05)$. In a similar study, Ornelas-Paz et al. (2010) pointed out that boiling apricots resulted in a gradual increase in the content of TP of all pungent taste from 1745.9 to $2549.7 \mu \mathrm{g}$ GAE/g WW. Also, Turkmen et al. (2005) found that some processing methods (such as boiling) resulted in an increase $(2-26 \%)$ in phenolic peppers content.

Moreover, when compared the total phenolic contents of puree $(94.55 \pm 0.42)$ and boiled samples (58.61 \pm 0.33 ), which had comparable preparation steps except for the last step in making puree, it could be stated that there was a statistically significant variation between them $(P \leq 0.05)$. It is also noted that mechanical compression in making puree changed the total phenolic composition substantially $(P \leq 0.05)$.

The lowest total phenolics content was exhibited for apricot juice (on wet basis), with a reduced total phenolics content compared to other samples (Figure 2). This outcome can be clarified by the degradation of phenols induced primarily by the enzyme polyphenol oxidase (Fang et al., 2008).

The phenolic compounds found in apricots are (flavonoids and phenolic acids) and total phenolic content was registered at 50.00-563.00 mg GAE/100g on the basis of wet weight (Ali et al., 2011). Factors that result in variations in phenolic concentrations include agricultural and climatic factors, genotype, storage conditions and ripeness degree (Spanos and
Worlstad,1992). Phenolics concentration level usually improves as the fruit grows and reaches the stage of full maturity; but, the level of phenolic components sometimes decreases as the fruit fully ripens (DragovicUzelac et al., 2007). However, some experiments have also shown elevated levels of phenolics in semi-mature apricots (Kalyoncu et al., 2009).

The phenolic acids like isochlorogenic, neochlorogenic, chlorogenic, caffeic, $\beta$-coumaric, ferulic acids and p-coumaric components are the most common found in apricot (Sass-Kiss et al., 2005)

Iordanescu et al. (2018) indicated that the dynamics of total phenolics for different cultivated apricot species were linked with the maturation process and an important increase in total phenolics as the apricot fruit grows. Similar findings were achieved from Hegedüs $e t$ al. (2011). On the other hand, Cosmulescu et al. (2018) point out that the greatest amount of polyphenols was shown in non-ripen apricots, that reduced in semimature fruit, and did not alter significantly in ripe fruit.

\section{The total content of flavonoid}

The contents of total flavonoids in raw and in apricot processed at home are shown in (Figure 3). The Figure shows that puree preparation raised the content of total flavonoids in a wet sample to $(83.21 \pm 0.82 \mathrm{mg})$ in comparison with the total content of flavonoids of raw wet sample $(49.16 \pm 0.80 \mathrm{mg})$. In a similar study, puree preparation has been revealed to provide up to a double rise in the total flavonoids content of raw tomatoes on a fresh weight basis (Kamiloglu et al., 2014). On the other hand, the boiling method, which has comparable handling parameters with the process of making puree with the exception of the last step of pureeing, has comparable influence on puree preparation (Figure1). Moreover, puree and boiling preparation caused a significant statistically variation in the total contents of flavonoids of the raw apricot $(P<0.05)$. This increase in total flavonoids values may be linked to high levels of free extracted flavanols (Turkmen et al., 2005).

The highest total flavonoids content was exhibited for apricot jam, having a high total flavonoids content in comparison to raw, boiled and juice. The methods of cooking is capable of inactivating the oxidase enzyme of polyphenol during heating, which inhibits the degradation of polyphenols (Chuah et al., 2008). Thermal processing may release more bound polyphenols from the breakdown of cellular constituents. Furthermore, heating may also deactivate apricot polyphenol oxidase and prevent the loss of polyphenols by enzymatic browning. 


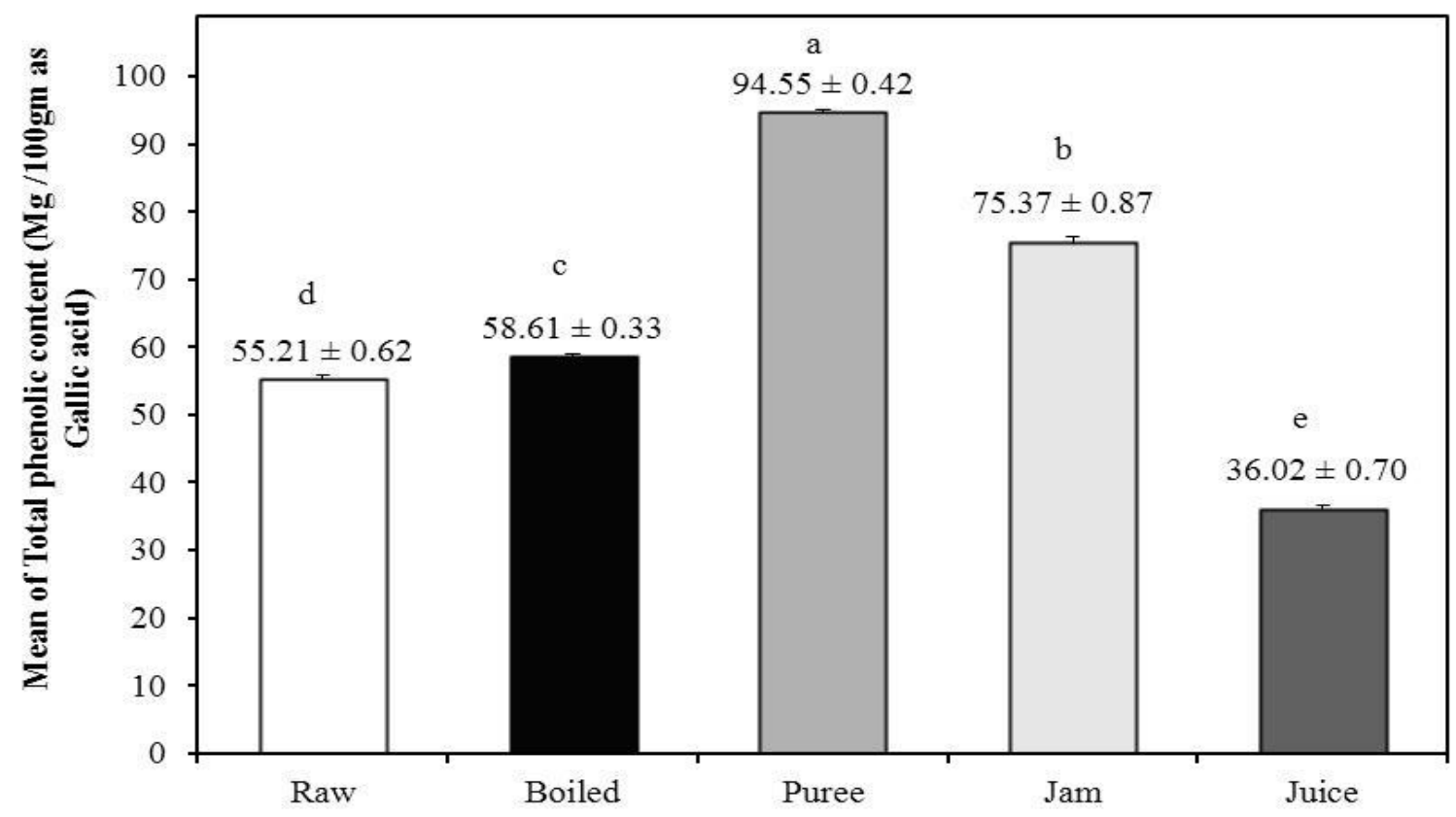

Fig. 2. Total phenolic content of home processing methods for apricot products (mg $/ 100 \mathrm{~g}$ as Gallic acid)

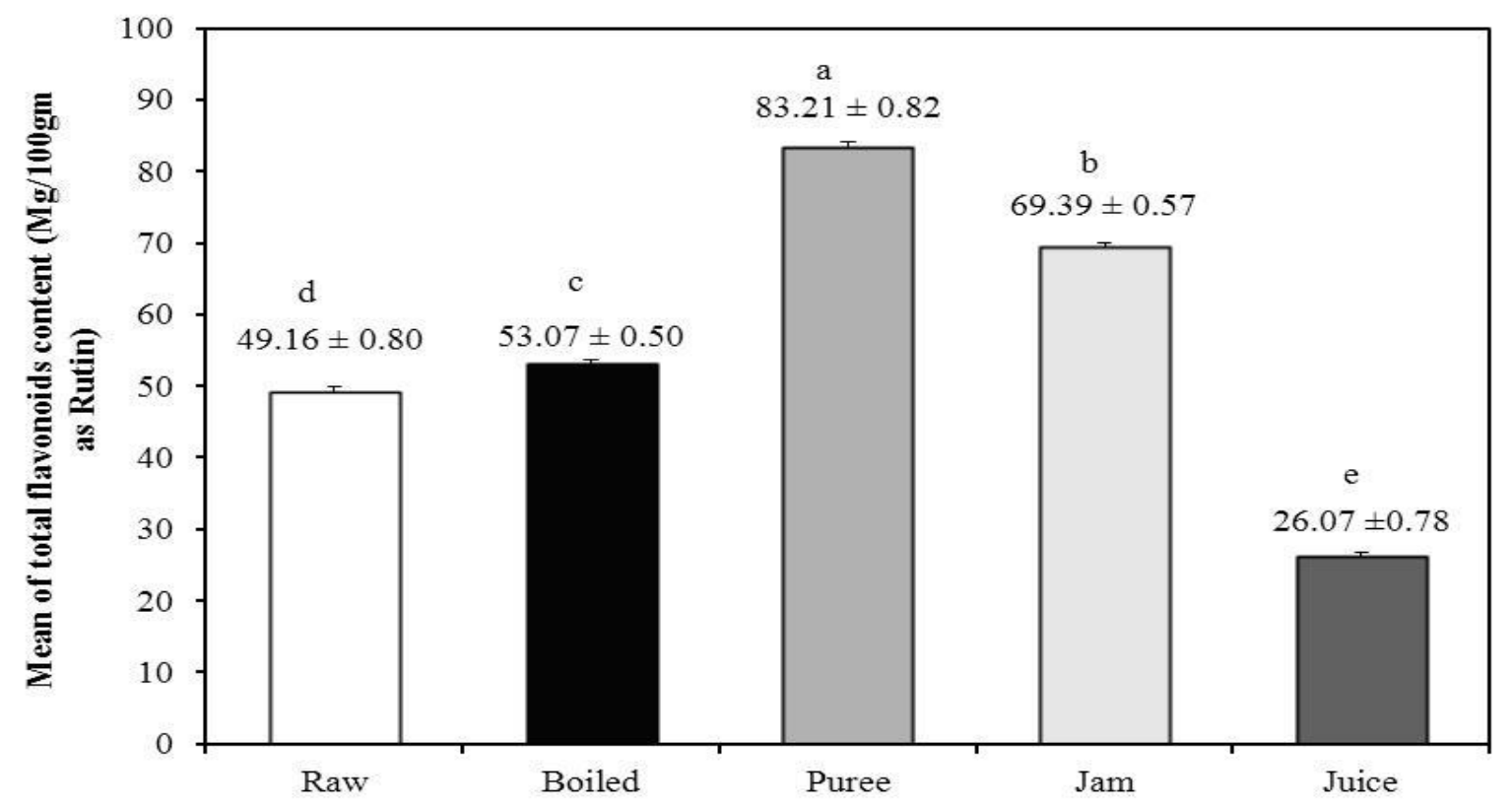

Fig.3. Total flavonoids content of home processing methods for apricot products (mg/100g as Rutin) 
Ravichandran et al. (2012) found that the contents of quercetin for tomatoes and onions were assessed after heating many times through boiling, frying, and cooking in the microwave, and the result were $75 \%-80 \%, 20 \%-$ $35 \%$ increases and a $65 \%$ decrease, respectively.

Total flavonoids content of apricot juice, which also included mechanical stress during juice extraction step, caused a reduced total flavonoid content on a wet basis (26.07 $\pm 0.78 \mathrm{mg} \mathrm{RE} / 100 \mathrm{~g}$ sample) than that of the raw apricot. The processing of the apricot samples included boiling, pureeing, and juicing via heat and/or mechanical compression. The preparation of juice is made by mechanical compression; while puree preparation is not done only by mechanical compression but also via thermal process. Although the heat treatment resulted in a change in the total flavonoids content in boiled apricot, mechanical compression caused a double reduction in the total content of flavonoids in the sample of apricot juice; the heat treatment together with the mechanically stress caused an increase of total flavonoids content in apricot puree compared to the raw apricot sample on wet basis.

\section{Total Antioxidant capability}

The impacts of the various ways of processing apricot fruit at home on total antioxidant capacity of apricot was assessed via DPPH test as shown in (Table 3 ). puree and jam preparation significantly changed the total antioxidant capacity values on a wet basis compared to fresh apricot. In addition, boiling, puree, jam were found to cause a significant increase in total antioxidant capacity compared to the raw apricot on wet basis (Table 3$)(P \leq 0.05)$.

The apricot puree samples represented the highest wet weight content $(85.29 \pm 0.13)$, while the lowest TAC values were recorded for boiled apricot and juice $(79.10 \pm 0.19$ and 52.03 \pm 0.65 , respectively).This reduction in antioxidant activities for juice sample could be related to their relatively lower total phenolic compared to the other home-processed apricot samples.
The TAC of apricot products has been shown to be mainly affected by the TP levels in this product. This agrees with Barba et al. (2013), who reported that the TP content can be regarded as a major pointer for antioxidant capacity that can be utilized as a preparatory screen for any sample when intended as a natural source of antioxidants in functional foods.

Table (3) shows the $\mathrm{IC}_{50}$ values of the samples of raw apricot, boiled, puree, jam and juice. The $\mathrm{IC}_{50}$ shows that there was a highest increase in apricot juice $(96.10 \pm 0.36)$ followed by the boiled $(37.93 \pm 0.84)$, fresh apricot $(37.35 \pm 0.66)$, jam $(24.07 \pm 0.35)$ and the lowest in puree $(23.45 \pm 0.53)$. Many studies have shown the great dietary values of apricot as a protective food as long as there are radical scavenging activities (Leccese et al.,2007). However, the variations in the level of effect have been reported while comparing distinct experiment technologies (Kalyoncu et al., 2009). The variations could be ascribed to the genotype, the phase of maturity, the geographical area and the standard which utilized as a reference compound.

\section{Carotenoids content}

The carotenoids content of apricot products is presented in (Figure 4). Boiled apricot showed a higher carotenoids content $(46.72 \pm 0.88 \mu \mathrm{g} / \mathrm{g})$ than puree and Juice $(44.57 \pm 0.35 \mu \mathrm{g} / \mathrm{g}$ and $43.42 \pm 0.77 \mu \mathrm{g} / \mathrm{g}$, respectively). There were no significant differences between puree and raw apricot. This is in agreement with the previous published data by Giuferida et al. (2013), who found that the carotene content remained virtually unchanged in all samples and was not affected by various treatments during the production of peach juice, jam and other products. Moreover, the differences were small in the relative contents of the components selected between the samples examined.

The lowest value of carotenoids content was traced in jam $(38.35 \pm 0.37 \mu \mathrm{g} / \mathrm{g})$. This may be due to the addition of sugar in large quantities, which reduced the concentration of carotenoids. The increase in carotenoids content in the boiled apricot is in accordance with the outcomes of Sanchez-Moreno et al. (2006)

Table 3. Antioxidant activity of apricot products

\begin{tabular}{cccccccc}
\hline Parameters & \multicolumn{9}{c}{ Home processing methods } & \multirow{2}{*}{ F } & p \\
\cline { 2 - 6 } & $\begin{array}{c}\text { Raw } \\
(\mathbf{n = 3})\end{array}$ & $\begin{array}{c}\text { Boiled } \\
(\mathbf{n = 3})\end{array}$ & $\begin{array}{c}\text { Puree } \\
(\mathbf{n = 3})\end{array}$ & $\begin{array}{c}\text { Jam } \\
(\mathbf{n = 3})\end{array}$ & $\begin{array}{c}\text { Juice } \\
(\mathbf{n = 3})\end{array}$ & & \\
\hline $\mathrm{DPPH} \%$ & $80.32 \pm 0.43^{\mathrm{c}}$ & $79.10 \pm 0.19^{\mathrm{d}}$ & $85.29 \pm 0.13^{\mathrm{a}}$ & $83.09 \pm 0.64^{\mathrm{b}}$ & $52.03 \pm 0.65^{\mathrm{e}}$ & $2590.87^{*}$ & $<0.001^{*}$ \\
$\mathrm{IC}_{50} \mathrm{mg} / \mathrm{ml}$ & $37.35 \pm 0.66^{\mathrm{b}}$ & $37.93 \pm 0.84^{\mathrm{b}}$ & $23.45 \pm 0.53^{\mathrm{c}}$ & $24.07 \pm 0.35^{\mathrm{c}}$ & $96.10 \pm 0.36^{\mathrm{a}}$ & $8062.35^{*}$ & $<0.001^{*}$ \\
\hline
\end{tabular}

F: F for ANOVA test, Pair wise comparison bet. each 2 groups was done using Post Hoc Test (LSD)

$\mathrm{p}: \mathrm{p}$ value for comparing between the studied groups

Means with Common letters are not significant (i.e. Means with Different letters are significant)

*: Statistically significant at $\mathrm{P} \leq 0.05$

Data were expressed using Mean \pm SD . 


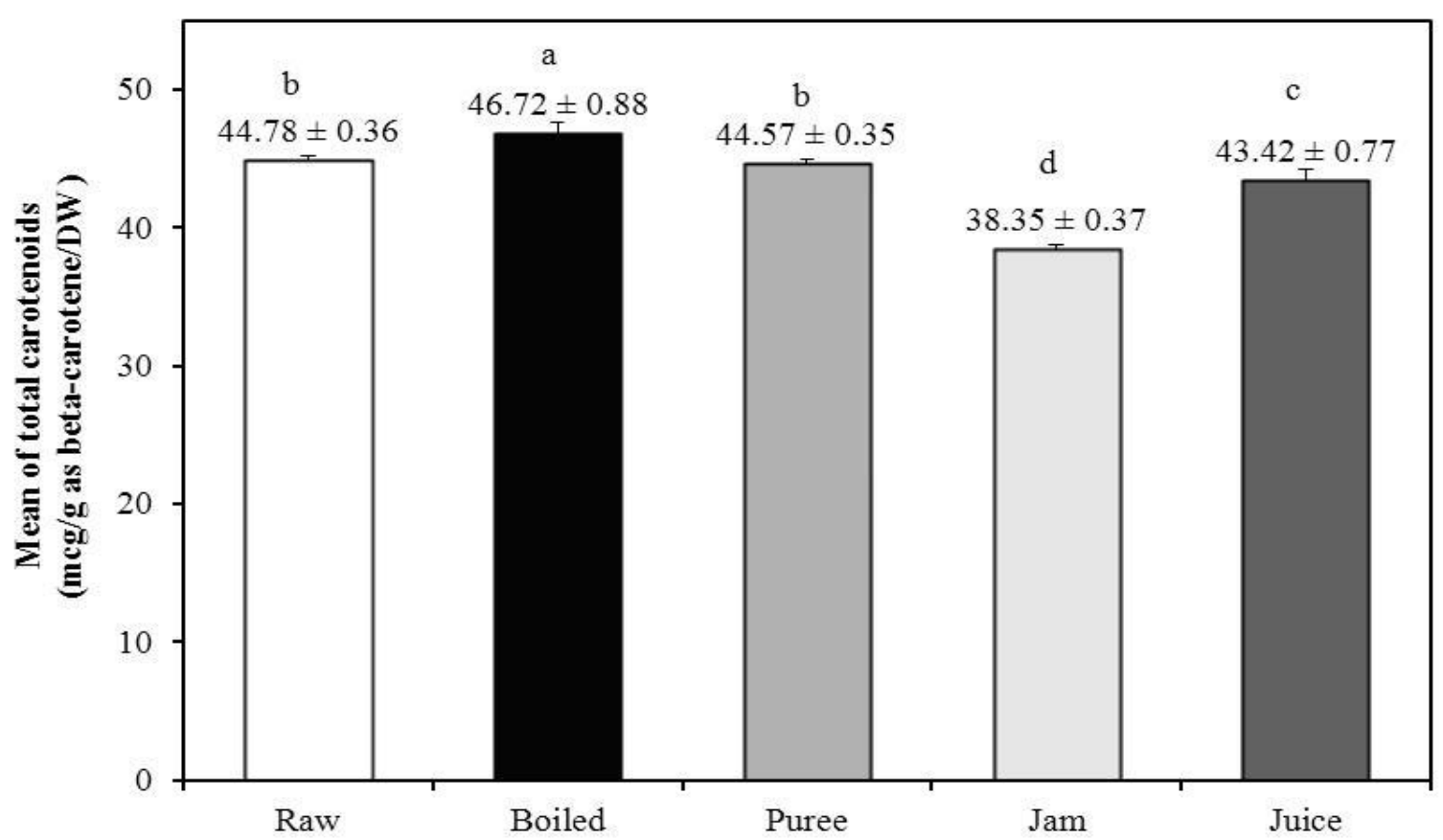

Fig. 4. Total carotenoids content of home processing methods for apricot products ( $\mu / \mathrm{g}$ as beta-carotene/DW)

who indicated that after exposure to $400 \mathrm{MP}$ a pressure at $25{ }^{\circ} \mathrm{C}$ for $15 \mathrm{~min}$, there was a $35 \%$ rise in $\beta$ carotene extractability, but heat treatment at $90{ }^{\circ} \mathrm{C}$ for $1 \mathrm{~min}$ caused $9 \%$ increase in $\beta$-carotene. Several results have also shown that by cell wall disturbance and heating there was an improvement in the bioavailability of some carotenoids (Russell, 2001).

Hwang et al. (2012) have shown that high temperature and long baking time make it easier for tocopherols and carotenoids to be released from tomatoes. In accordance, many researchers found significant $(P \leq 0.05)$ increment of $\beta$-carotene and lycopene in pumpkin as a result of cooking and stir frying. Such an effect can be explained on the basis that heat enhances the availability of the aforementioned compounds (Azizah et al., 2009).

Apricot is one of the fruits rich in carotene and the content ranges from $2.00-20.77 \mathrm{mg} / 100 \mathrm{~g}$ of $\beta$-carotene (Ali et al., 2011). The main carotenoids are $\beta$-carotene, lycopene and $\gamma$-carotene, but beta-carotene is found more often than other carotenoids. Apricot contains also lutein, $\beta$-cryptoxanthin, zeaxanthin, phytofluene and phytoene (Muller, 1997). In spite of the fact that there's no recommended daily intake for $\beta$-carotene, but a 3-6 mg every day admissions of $\beta$-carotene within the blood is thought to decrease the hazard of chronic disease
(De Rigal et al.,2000). Apricot is one of the most important food rich in provitamin A, because $250 \mathrm{~g}$ of fresh or $30 \mathrm{~g}$ of dried apricots give sufficient carotenoids to meet the body's vitamin A demands. (Fraser and Bramley, 2004).

\section{CONCLUSION}

In conclusion, the aim of this study was to examine the impact of the various ways of processing apricot fruits on total amount of apricots' antioxidant when produce as boiled, jam, juice and pureed. The results showed that the heat has a catalytic effect for total phenols, flavonoids and antioxidant activity. In addition, apricot juice provided lower values for total phenols and flavonoids contents, as well as for total antioxidant capacity when compared to the other apricot products. It is important to do a lot of research using different nutrients have antioxidants properties, using them fresh or cooked, in order to increase knowledge about the availability of these bioactive substances in different foods.

\section{REFERENCES}

Ahmadi, H., H. Fathollahzadeh and H. Mobli. 2008. Some physical and mechanical properties ofapricot fruits, pits and kernels (C.V. Tabarzeh). American-Eurasian Journal of Agriculture and Environmental Science. 3(5): 703-707. 
Ali, S., T. Masud and K.S. Abbasi. 2011. Physico-chemical characteristics of apricot (Prunusarmeniaca L.) grown in Northern Areas of Pakistan. ScientiaHorticulture.130(2): 386-392.

Ali, S., T. Masud, K. S. Abbasi, T. Mahmood and A. Hussain. 2015. Apricot: Nutritional Potentials and Health BenefitsA Review. Annals. Food Science and Technology. 16(1): 175-189.

Alpaslan, M. and M. Hayta. 2006. Apricot Kernel: Physical and Chemical Properties.Journal of American Oil Chemistry Society. 83(5):469-471.

Association of Official Analytical Chemists (AOAC). 2007. Official Methods of Analysis of the A.O.A.C. International $18^{\text {th }}$ ed. AOAC, Gaithersburg, Maryland, USA.

Association of Official Analytical Chemists (AOAC). 1990. Official Methods of Analysis (15th ed.). Arlington, VA: Author.

Ayour, J., M. Sagar, H. Harrak, A. Alahyane and M. Benichou. 2017. Evolution of some fruit quality criteria during ripening of twelve new Moroccan apricot clones (Prunusarmeniaca L.) ScientiaHorticulturae.215: 72-79.

Azizah, A. H., K. C.Wee, O. Azizah and M. Azizah. 2009. Effect of boiling and stir frying on total phenolics, carotenoids and radical scavenging activity of pumpkin (Cucurbitamoschato), International Food Research J.16: 45-51.

Barba, F. J., M. J. Esteve, P. Tedeschi, V. Brandolini and A. Frigola. 2013. A comparative study of the analysis of antioxidant activities of liquid foods employing spectrophotometric, fluorometric, and chemiluminescent methods. Food Analytical Methods. 6: 317-327.

Campbell, O.E., I.A. Merwin and O.I. Padilla-Zakour. 2011. Nutritional quality of New York peaches and apricots. New York Fruit Quarterly. 19(4):12-16.

$\mathrm{C}^{\sim}$ anadanovic'-Brunet, J. M., S.S. Savatovi', G.S. C'etkovic', J.J. Vulic', S.M. Djilas, S.L. Markov and D.D. Cvetkovic'. 2011. Antioxidant and antimicrobial activities of beet root pomace extracts. Czech. J. Food Sci. 29: 575-585.

Capanoglu, E., J. Beekwilder, D. Boyacioglu, R. Hall and R. De Vos. 2008. Changes in antioxidant and metabolite profiles during production of tomato paste. Journal of Agricultural and Food Chemistry. 56(3): 964-973.

Chauhan, S.K., S.M. Tyagi and D. Singh. 2001.Pectinolytic liquefaction of apricot, plum, and mango pulps for juice extraction. International Journal of Food Properties.4(1):103-109.

Choi M. H., G. H. Kima and H.S. Lee. 2002. Effectsof ascorbic acid retention on juice color andpigment stability in blood orange (Citrus sinensis) juice during refrigerated storage. Food ResearchInternational. 35(8):753-759.

Chuah, A. M., Y.C. Lee, T. Yamaguchi, H. Takamura, L. J. Yin and T. Matoba. 2008. Effect of cooking on the antioxidant properties of coloured peppers. Food Chemistry. 111(1): 20-28.
Cosmulescu, S., I. Trandafir, V. Nour, G. Achim, M. Botu and O. Iordanescu. 2018. Variation of bioactive compounds and antioxidant activity of Jujube (Ziziphusjujuba) fruits at different stages of ripenin. Notulae Botanicae Horti Agrobotanici Cluj-Napoca. 46(1):134-137.

De Rigal, D., F. Gauillard and F. Richard-Forget.2000. Changes in the carotenoid content of apricot (Prunusarmeniaca, var Bergeron) duringenzymatic browning: $\beta$-carotene inhibition of chlorogenic acid degradation. Journal of Science Food and Agricultural. 80:763-768.

Dragovic-Uzelac, V., B. Levaj, V. Mrkicm, D. Bursac and M. Boras. 2007.The content of polyphenols and carotenoids in three apricot cultivars depending on stage of maturity and geographical region. Food Chemistry.102:966-975.

Drogoudi, P.D., S. Vemmos, G. Pantedelis, E. Petri, C. Tzoutzoukou and I. Karayannis. 2008.Physical characters and antioxidant, sugar, and mineral nutrient contents in fruit from 29 apricot (Prunusarmeniaca L.) cultivars and hybrids. Journal of Agricultural and Food Chemistry. 56:10754-10760.

Egea, I. M., M.C. Martinez-Madrid, P. Sanchez-Bel, M. A. Murcia and F. Romojaro. 2007. The influence of electronbeam ionization on ethylene metabolism and quality parameters in apricot (Prunusarmeniaca L., cvBulida). Lebensmittel-Wissenschaft-Food Science and Technology. 40(6):1027-1035.

Erdogan-Orhan, I., and M. Kartal. 2011. Insights into research on phytochemistry and biological activities of Prunusarmeniaca L. (apricot). Food Research International. 44(5): 1238-1243.

Fang, Z., Y. Hu, D. Liu, J. Chen and X. Ye. 2008.Changes of phenolic acids and antioxidant activities during potherb mustard (Brassica juncea, Coss.) pickling. Food Chemistry. 108: 811-817.

Fraser, P.D. and P.M. Bramley. 2004. The biosynthesis and nutritional uses of carotenoids.Progress on Lipid Research. 43:228-265.

Fratianni, F., M.N. Ombra, A. d'Acierno, L. Cipriano and F. Nazzaro. 2018. Apricots: biochemistry and functional properties. Current Opinion in Food Science. 19: 23-29.

Giuferida, D., G. Torre, P. Dugo and G. Dugo. 2013. Determination of the carotenoid profile in peach fruits, juice and jam. Fruits.68:39-44.

Hacıseferoğulları, H., I. Gezer, M. M. Özcan and B. MuratAsma. 2007. Postharvest chemical and physical mechanical properties of some apricot varieties cultivated in Turkey. J. Food Engineering. 79(1):364-373.

Hegedüs, A., P. Pfeiffer, N. Papp, L. Abrankó, A. Blázovics, A. Pedryc and E. Stefanovits-Bányai. 2011. Accumulation of antioxidants in apricot fruit through ripening: characterization of a genotype with enhanced functional properties. Biological Research. 44:339-344.

Hussain, A., Y. Azra and A. Javed, 2010. Comparative study of chemical composition of some dried apricot varieties grown in northern areas of Pakistan. Pakistan Journal of Botany.42(4):2497-2502. 
Hussain, P.R., S. Chatterjee, P.S. Variyar, A. Sharma, M.A. Dar and A.M Wani. 2013. Bioactive compounds and antioxidant activity of gamma irradiated sun-dried apricots (Prunusarmeniaca L.) Journal of Food Composition and Analysis.30(2): 59-66.

Hwang E. S., M. Stacewicz-Sapuntzakis and P. E. Bowen. 2012.Effects of Heat Treatment on the Carotenoid and Tocopherol Composition of Tomato. J.of Food Sci. 77(10):C1109-C1114.

Iordanescu, O. A., E. Alexa, , D. Lalescu, , A Berbecea,., D. Camen, , M. A. Poiana, D. Moigradean, and M. Bala. 2018. Chemical composition and antioxidant activity of some apricot varieties at different ripening stages. Chilean Journal of Agricultural Research. 78(2):266-275.

Iordanescu, O.A., E. Alexa, , R. Micu, , and M.A. Poiana, 2012. Bioactive compounds and antioxidant properties of apples cultivars from Romania in different maturity stage. Journal of Food Agriculture and Environment. 10(1):147151.

Iordanescu, O.A., and R.E. Micu. 2012. Fruit culture and pomology. Eurobit Publishing, Timisoara, Romania.

Jimenez, A. M., M. Martınez-Tome, I. Egea, F. Romojaro and M. A. Murcia. 2008. Effect of industrial processing and storage on antioxidant activity of apricot (Prunusarmeniaca v. bulida). European Food Research and Technology. 227(1): 125-134.

Kalt, W. 2005. Effects of production and processing factors on major fruit and vegetable antioxidants. Journal of Food Science. 70(1):11-19.

Kalyoncu, I.H., M. Akbulut and H. Coklar. 2009. Antioxidant capacity, total phenolics and some chemical properties of semi-mature apricot cultivars grown in Malatya, Turkey. World Applied Science.6(4):519-523.

Kamiloglu, S., M. Demirci, S. Selen, G. Toydemir, D. Boyacioglu and E. Capanoglu. 2014. Home processing of tomatoes (Solanumlycopersicum): Effects on in vitro bioaccessibility of total lycopene, phenolics, flavonoids, and antioxidant capacity. Journal of the Science of Food and Agriculture. 94(11): 2225-2233.

Kotz, S., N. Balakrishnan, C.B. Read and B. Vidakovic. 2006. Encyclopedia of statistical sciences, $2^{\text {nd }}$ edn, WileyInterscience, Hoboken, N.J.

Leccese, A., S. Bartolini and R. Viti. 2007.Total antioxidant capacity and phenolics content in apricot fruits. International Journal of Fruit Sci.7(2):3-16.

Leccese, A., S. Bureau, M. Reich, C. Renard, J.C. Audergon, C. Mennone, S. Bartolini and R. Viti. 2010. Pomological and nutraceutical properties in apricot fruit: Cultivation systems and cold storage fruit management. Plant Foods Human Nutrition. 65:112-120.

Muller, H. 1997. Determination of the carotenoid content in selected vegetables and fruit by HPLC and photodiode array detection. Zeitschriftfür Lebensmitteluntersuchung und -Forschung A. 204(2): 88-94.
Murcia, M. A., B. Lopez-Ayerra, M. Martinez-Tome and F. Garcia-Carmona. 2001. Effect of industrial processing on amino acid content of broccoli. Journal of the Science of Food and Agriculture.81(14):1299-1305.

Negrea, M., I. Radulov, L. Ardelean and L.C. Rusu. 2012. Mineral nutrients compositions of Daucuscarota culture in different stages of morphogenesis.Revista de Chimie (Bucharest). 63(9):887-892.

Nielsen, S.S. 1994. Introduction to the chemical analysis of foods. Boston: Jones and Bartlett.

Ornelas-Paz, J., J. M. Martínez-Burrola, S. Ruiz-Cruz, V. Santana-Rodríguez, V. Ibarra-Junquera, G. I. Olivas and J. D. Pérez-Martínez. 2010. Effect of cooking on the capsaicinoids and phenolics contents of Mexican peppers. Food Chemistry.119(4):1619-1625.

Ravichandran, K., A.R. Ahmed, D. Knorr and I. Smetanska. 2012. The effect of different processing methods on phenolic acid content and antioxidant activity of red beet. Food Res. Int. 48:16-20. [CrossRef]

Russell, R.M. 2001. Lycopene and Lutein: the next steps to the mixed carotenoids. In: Kramer K, Hoppe PP, Packer L, (eds.). Nutraceuticals in health and disease prevention. New York: Marcel Dekker. p.23-43.

Sanchez-Moreno, C., L. Plaza, B. de Ancos and M.P. Cano. 2006. Impact of high-pressure and traditional thermal processing of tomato puree on carotenoids, vitamin $\mathrm{C}$ and antioxidant activity. Journal of the Science of Food andAgriculture. 86(2):171-179.

Sass-Kiss, A., J. Kiss, P. Milotay, M.M. Kerek and M. TothMarkus. 2005. Differences in anthocyanin and carotenoid content of fruits and vegetables. Food Research International. 38:1023-1029.

Schweiggert, U., A. Schieber and R. Carle. 2006. Effects of blanching and storage on capsaicinoid stability and peroxidase activity of hot chili peppers (Capsicum frutescens L.). Innovative Food Science and Emerging Technologies. 7(3):217-224.

Sefer, F., A. Misirli and R. Gülcan, 2006. A research on phenolic and cyanogenic compounds in sweet and bitter apricot kernels. Acta Horticulturae. 701:167-169.

Singh, R., K. Chidambara Murthy and G. Jayaprakasha. 2002. Studies on the antioxidant activity of pomegranate (Punica granatum) peel and seed extracts using in vitro models. J. Agric. Food Chem. 50:81-86.

Soetan, K.O., C.O. Olaiya and O.E. Oyewole. 2010. The importance of mineral elements for humans, domestic animals and plants: A review. African Journal of Food Sci.4(5):200-222.

Spanos, G.A., and R.E. Wrolstad. 1992. Phenolics of apple, pear and white grape nectars and their changes with processing and storage.Journal of Agricultural and Food Chemistry. 40(9):1478-1487.

Turkmen, N., F. Sari and Y.S. Velioglu. 2005. The effect of cooking methods on total phenolics and antioxidant activity of selected green vegetables. Food Chemistry.93:713-718. 
(USDA) United States Department of Agriculture, National Nutrient Database for Standard Reference Legacy Release. 2005. Nutrition facts and information for apricots, raw. Available from: http://www.nutritiondata.com.

Wani, S.M., F.A. Masoodi, T. A. Wani, M. Ahmad, A. Gani and S.A. Ganai,. 2015. Physical characteristics, mineral analysis and antioxidant properties of some apricot varieties grown in North India. Cogent Food and Agriculture.1:1118961.
Xu, G., X. Ye, J. Chen and D. Liu. 2007. Effect of Heat Treatment on the Phenolic Compounds and Antioxidant Capacity of Citrus Peel Extract. Journal of Agricultural Food Chemistry.55(2): 330-335.

Yildiz, F. 1994. New technologies in apricot processing. Journal of Standard, Apricot Special Issue, Ankara, Turkey.1994:67-69.

\section{الملخص العربي}

\section{تأثثر طرق الإعداد المنزلي على الخصائص المضادة للأكسدة لبعض منتجات المشمش}

$$
\text { استير فيكتور عبد النور }
$$

البيورية والمربى ذات محتوى أعلى من النشاط المضاد

للأكسدة بالمقارنة بباقي المنتجات. ولم نوجد فروق معنوية

ذات دلالة في محتوى الكاروتينات بين كلا من المشمش

الطازج و المسلوق و البيورية و المربى و العصير • يقدم هذا

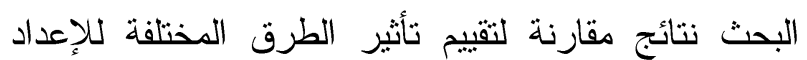

المنزلي على النشاط المضاد للأكسدة لبعض منتجات

$$
\text { المشمش. }
$$

الكلمات المفتاحية: المشمش- الفينولات الكلية-

الفلافونيدات الكلية- الكاروتينات- النشاط المضاد للأكسدة-
يهدف هذا البحث إلى دراسة تأثير إعداد ثمار المشمش

بطرق مختلفة في المنزل على العناصر المضادة للأكسدة.

تم فحص المشمش الخام و المسلوق و البيورية و العصير و المربى بعد إعدادهم منزليا من حيث محتواهم من الكاروتينويدات و الفلافونويدات و الفينولات الكلية واجمالى النشاط المضاد للأكسدة. أوضحت النتائج أن المشمش غنى ولى ولى بالألياف و العديد من العناصر المعدنية وأهمها البوتاسيوم و الفسفور .ووجد أن البيورية والمربى يحتويان على أعلى ولى قيمة للمركبات الفينولية و الفلافونيدات بالمقارنة بالمشمش

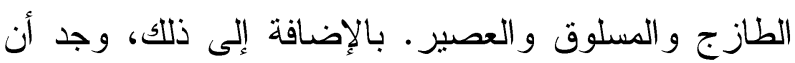

